\title{
RE-DISCOVERY OF MESOGLOEA BRASILIENSIS MONTAGNE
}

\author{
by Aylthon B. Joly \\ Department of Botany, University of S. Paulo, Brazil
}

As is common, many plants deseribed long ago have not been reported since their first discovery. This is the ease with many Brazilian species. As early as 1843, Montagne in his "Quatrième centurie de plantes cellulaires éxotiques nouvelles, Décade VII', on p. 304-305 under n. ${ }^{\circ} 68$, gave a brief description of a new species, which he ascribed to the genus Mesogloea and to which he gave the specific name brasiliensis. The material had been collected by Gaudichaud ( $n^{\circ} 51$ fide Kützing, 1849, p. 534 ) in the vicinity of Rio de Janeiro, Brazil.

Three years later, the same author, reporting the algae collected during the "Voyage de la Bonite" (1846 Tome I p. 28-29) gave a long and more complete diagnosis of the same plant. Unfortunately this second description, giving accurate microscopic measurements, was completely overlooked after its publication, until the present writer, by happy chance, came across this supplementary diagnosis. The references so far found in the literature are concerned exclusively with the first description: ef. Agardh (1848 p. 58), Kützing (1849 p. 534), De Toni (1895 p. 427), Taylor (1931 p. 294), Levring (1939 p. 46). Kylin (1940) in his monograph of the family Chordariaceae, nnfortunately did not even mention the plant.

We think it is now proper to give a description, photograph and drawings based on new collections recently made by the author, on the assumption that our plant and Montagne's are identical. (See later discussion).

\section{Levringia brasiliensis (Montagne) comb. nov.}

Plants up to $10-13 \mathrm{~cm}$ high (commonly $6-8 \mathrm{~cm}$ ) and $1,1 / 2-2 \mathrm{~mm}$ in diameter, brown-greenish in colour when alive and adhering well to the paper when dried under pressure; sparingly ramified at the base, usually with one predominant branch, more or less eylindrical throughout. Holdfast distinet, originating from a basal dise (ef. Parke, 1933 p. 8) but no longer recognisable in the adult plant, firm, formed by the compacted medullary filaments which are coloured deeply by a yellow-brown substance.

Thallus composed of two distinct portions: a medulla with colourless filaments running from apex to base, and a cortical layer formed of 
filaments radially disposed and richly ramified. For an account of the general internal organization see Kuckuck (1929), Parke (1933) and Kylin (1940).

Medullary filaments composed of elongated cells, $56 \times 9,6 \mu$ (Plate 1 fig. 1) with very thin walls, usually dichotomizing before giving off the assimilatory layers. Partition membranes sometimes euriously sinuated. The medullary filaments and the rhizoid-like outgrowth from them are interwoven, forming a rather firm pseudo-parenchyma. The rhizoids running longitudinally or perpendicularly to the medullary filaments, grow out from special cells which are small, sub-quadrate to rectangular and placed at irregular intervals between the elongated cells of the medullary threads. These rhizoids appear as opposite pairs or in threes, have a diameter of about $4,8 \mu$, are formed of elongated cells with a more or less irregular outline.

The cortical portions are formed by filaments starting from the medulla, having in their basal parts cells bearing rhizoid-like formations which are slightly thicker than those of the medulla $(6-9 \mu$ in diameter). The cortical filaments are composed of very irregular cells at their bases, with more or less round outlines (Plate 1 fig. 2) varying from 16 to $48 \mu$ in length and about 16 to $22 \mu$ in diameter. The ramifieation is abundant, usually dichotomous, chiefly basal. Assimilatory filaments measure up to $1035 \mu$ in their free unramified portion, with cells reaching 14-16 $\mu$ (diameter) and $12 \mu$ in length at the base. The upper portions (Plate $1 \mathrm{fig}$. 4) have much more elongated cells, up to $40 \mu$ in lenght. Cells of the assimilatory filaments and some of the upper cells of the cortical portions are filled with chromatophores. These chromatophores are small, appearing as round bodies not very numerous in each cell.

Plurilocular sporangia (Plate 1 figs. $3,5,6$ ) are terminally placed on special lateral branchlets starting from the very base of the assimilatory filaments. The size is variable, up to $125 \mu$ long (slightly longer than Montagne's measurements) and with a diameter of $25.6 \mu$ in the broader part, and ending in an usually rounded tip, with a more or less irregular shape. The sporangia are quite distinct from the surrouding filaments by their dense and dark contents. Unilocular sporangia were not found. *

The plant above described and figured (see fig. 1) seems to us to represent the same species once found by Gaudichaud and described by Montagne as Mesogloea brasiliensis. Unfortunately the deseriptions alone are not sufficient to secure a complete identification. The plant, being the only known member of the family Chordariaceae assigned to Brazil (cf. Taylor 1931, p. 294) is quite probably identical with that of the earlier collection.

(*) After I saw the first proofs of this paper I received through the kindness of Dr. J. Feldmann of the "Institut Océanographique" of the University of Paris, drawings and measurements of the plurilocular sporangia taken from Montagne's original plant. They are in accordance with the measurements presented in this paper. I wish to express my best thanks to Dr. Feldmann for his interest. 
Levring (1939 p. 46), is of the opinion that the plant is identical to Levringia sordida (Bory) Kylin, and though he had never seen the original material or new collections of $M$. brasiliensis, he placed it under the synonymy of the first mentioned species, in this particular agreeing with the earlier opinion of Kützing (1849 p. 534 under Thorea), who had the opportunity of seeing the original plant. Kylin (1940), apparently accepted this point of view because he did not refer to this species when he monographed the family.

Apparently the only reason why the plant has passed under the synonymy of $L$. sordida, is the careful treatment by Montagne, who, knowing the plant referred to by Bory only by its name (ef. Montagne 1843 and 1846) and thinking it better to give a new name to his plant, possibly because the plant had been found in a locality so far distant from that reported by Bory, stated nevertheless his suspicion of its possible identity with Bory's plant.

Levringia sordida (Bory) Kylin has been found on Ascension Island (South Atlantic) and from the figures given by Levring (1.c. p. 45, fig. $3 \mathrm{~F}-\mathrm{G}$ ) one can see that his plant and ours are morphologically closely related but by no means identical - compare with our figure 5 . Our plant has the sporangia placed on special short and ramified branchlets, located at the base of the assimilatory filaments, forming groups at least of four sporangia for each primary branchlet and not like the ones figured by Levring. Our plant seems to be about the same size but slightly thicker than $L$. sordida, as compared with the measurements given by Bory (1828 p. 139) and Levring (1. c. p. 46), L. sordida has sporangia up to $125 \mu$ long and $14 \mu$ broad. The cells of the assimilatory filaments are up to $30 \mu$ long and $15 \mu$ broad. These measurements are of course within the range of variation found in our species, being the mature sporangia of our plant about $10 \mu$ wider than those of $L$. sordida, but this apparently has no sharp specific value, if we accept Kylin's concept of species in this genus. Cf. Kylin 1940, where he gives equal measurements (for sporangia and assimilatory filaments) to 3 different species: $L$. natalensis, $L$. filiformis and L. Börgesenii (ef. Kylin l. e. p. 15-16).

From the other six species of the genus, $\left({ }^{*}\right)$ L. brasiliensis is easily distinguished by its structural features being the only known species with a relatively broad sporangia - up to $25.6 \mu$ of diameter. Nevertheless it elearly belongs to the group of species which includes: $L$. sordida (Bory) Kylin and $L$. atlantica (Feldm.) Kylin, both from South Atlantic and $L$. Decaryii Feldm., from Madagasear, recently deseribed by Feldmann,

(*) By the time I saw the second proofs of this paper, Prof. Pierre Dangeard, of the Faculté des Sciences de Bordeaux, very kindly sent me on request his: "Algues de la presqu' île du Cap Vert (Dakar) et de ses environs". Le Botaniste 36,1-6: 195-329 (incl. pl. XIV-XXI). 1952. On pages 234-237 two species of Levringia are studied by Dr. J. Feldmann: L. atlantica and Levringia sp. Dr. J. Feldmann suggests the possible identity of this plant with Montagne's Mesogloia brasiliensis var. natalensis of earlier record in that region. 
(1945) all of which possess rather long sporangia. The remaining species: L. natalensis (Kütz.) Kylin, L. filiformis Kylin and $L$. Börgesenii Kylin have a relatively short and somewhat broad sporangia (Cf. measurements given by Kylin, 1946).

The plant has been found in a very limited area on the southern coast of Brazil. It has been collected abundantly in the following localities: Itanhaen ( $24^{\circ} 9^{\prime}$ Lat. S., $46^{\circ} 47^{\prime}$ Long. W.) and Peruibe, both in the State of S. Paulo; Matinhos, Caiobá and Guaratuba (25 $52^{\prime}$ Lat. S., $48^{\circ} 35^{\prime}$ Long. W.) in the State of Paraná. Fruiting material was collected during the months of November to February. $\left(^{1}\right)$

It is interesting to note that the plant, actually a component of the intertidal association on the rocky shores of Southern Brazil, is frequently found growing upon Mytilus, one of the organisms characteristic of certain coastal features in the tropical South Atlantic, and thus on the same substrate as reported by Montagne (1843 p. $305 ; 1846$ p. 29).

\section{Acknowledgments}

This paper was prepared under a fellowship sponsored by The Rockfeller Foundation, at the Department of Botany, University of Michigan. For the facilities provided here I am greatly indebted to Prof. K. L. Jones, Chairman of the Department and to Prof. Wm. R. Taylor for continuous assistance. Mr. John Blum kindly revised the manuscript. In connection with this study the author has had the opportunity of seeing fragments of authentic material of Levringia natalensis (Kütz.) Kylin, through the kindness of Prof. G. F. Papenfuss.

\section{RESUMO}

No presente trabalho o autor refere o achado de uma planta coletada uma única vez no litoral sul do Brasil. Além de uma nova descrição é também proposta uma nova combinação em conformidade com a moderna nomenclatura ficológica.

\section{BIBLIOGRAPHY}

AGARDH, J. G. 1848, Species Genera et Ordines Algarum. I: I-VIII + 1-363. Lund. BORY DE ST. VICENT, J. B. 1828, Botanique. Cryptogamie, in L. I. Duperrey. Voyage autour du monde... La Coquille: 97-200. Paris.

(1) When this paper was finished the author reeeived from Prof. Wm. $R$. Taylor, Uruguayan material, collected by D. Legrand (n.o 3705) which proved to be the same species referred to above, thus increasing much the area of distribution of Levringia brasiliensis. Some of the Uruguayan specimens seen are a little more ramified at the base than some of the Brazilian plants. 
DE TONI, J. B. 1895, Sylloge Algarum. 3: I-XVI + 1-638. Padova.

FELDMANN, J. 1945, Une nouvelle espèce de Levringia (Phaeophyceae, Chordariales) du Sud de Madagasear. Bull. Mus. 2e. sér. 17 (4): 340-341.

KUCKUCK, P. 1929, Fragmente einer Monographie der Phaeosporen. Herausgegeben von W. Nienburg. Wissenseh. Meeresunters. Kom. zur Unters. der Deutsch. Meere in Kiel u. der Biol. Aust. auf Helgoland. N. F. Abt. Helgoland. Bd. 17 Abhand. 4: 1-93.

KUTZING', F. T. 1849, Species algarum. 1-922. Leipzig.

KYLIN, H. 1940, Die Phaeophyceenordnung Chordariales. Lunds Univ. Arssk. N. F. Avd. 2 Bd. 36 (9): $1-67.8 \mathrm{pl}$.

LEVRING, T. 1939, Über die Phaeophyceengattungen Myriogloia Kuck. und Haplogloia nov. gen. Botan. Not. 1939: 40-52.

MONTAGNE, J. F. C. 1843, Quatrième centurie de plantes cellulaires éxotiques nouvelles. Décade VII. Ann. Se. Nat. Bot. 2e. sér. 20: 294-306.

MONTAGNE, J. F. C. 1846, In C. Beaupré Gaudichaud, Botanique. Cryptogames cellulaires. Algues, lichens, hépatiques et mousses. "In" A. N. Vaillant, "Voyage autour du monde exécuté pendant... la Bonite”. 1: I-XI +1-355. Paris.

PARKE, M. 1933, A contribution to knowledge of the Mesogloiaceae and associated families. Publ. of the Hartley Bot. Lab. 9: 1-43. Pl. I-XI. Liverpool.

TAYLOR, Wm. R. 1931, A synopsis of the marine algae of Brazil. Rev. Alg. 5 $(3-4): 279-313$. 


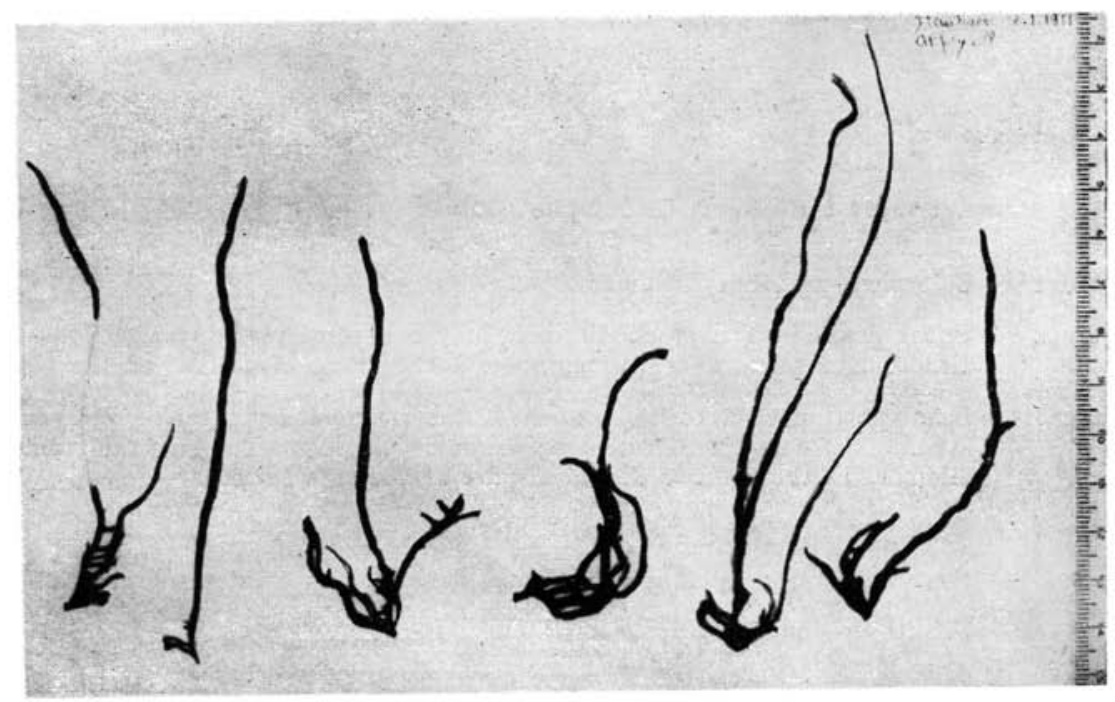

TEX'T FIG. 1

Levringia brasiliensis (Montagne) Joly

Group of six plants from Itanhaen, S. Paulo. 
Figure 1 - Colourless medullary filament.

Figure 2 - Basal portion of a sterile branch in the assimilatory layer. Note the dichotomous pattern of branching and the rounded outline of the eells.

Figure 3 - Basal portion of a fertile branch of the assimilatory layer. Four young sporangia are seen in different stages of development. The long unbranehed filament at the right is the basal part of the free assimilator.

Figure 4 - Upper portion of a free assimilator.

Figure 5 - Four developing sporangia, growing from a single lateral branchlet.

Figure 6 - Mature sporangia. 


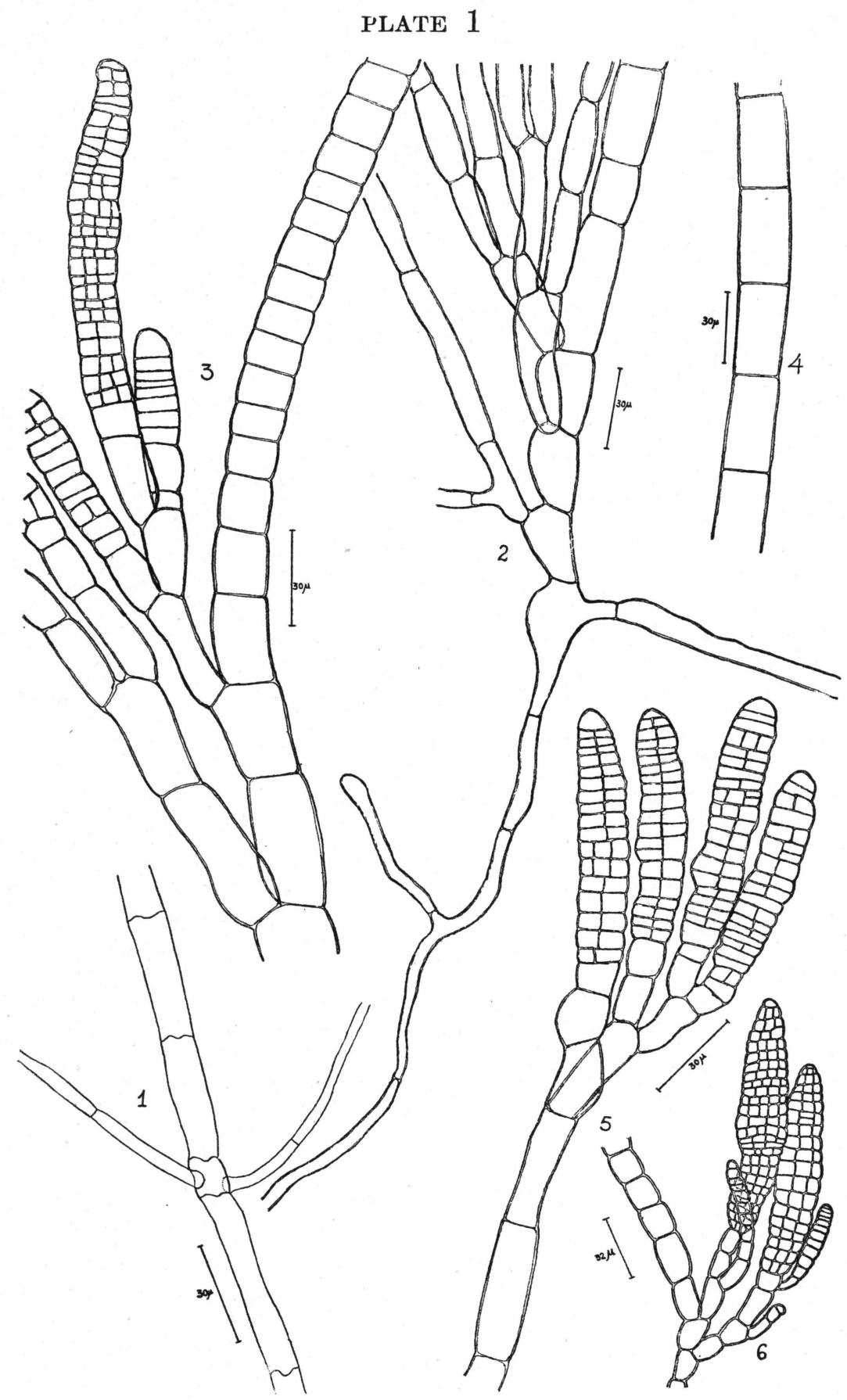

